\title{
Structural and functional characterization of tree proteins involved in redox regulation: a new frontier in forest science
}

\author{
Jean-Pierre Jacquot • Jérémy Couturier • Claude Didierjean • \\ Eric Gelhaye • Mélanie Morel-Rouhier • Arnaud Hecker • \\ Christophe Plomion • Desirée D. Gütle • Nicolas Rouhier
}

Received: 12 September 2014 / Accepted: 14 November 2014 /Published online: 5 December 2014

(C) INRA and Springer-Verlag France 2014

\begin{abstract}
- Key message This paper describes how the combination of genomics, genetic engineering, and 3D structural characterization has helped clarify the redox regulatory networks in poplar with consequences not only in system biology in plants but also in bacteria and mammalian systems.

- Context Tree genomes are increasingly available with a large number of orphan genes coding for proteins, the function of which is still unknown.
\end{abstract}

\footnotetext{
Handling Editor: Jean-Michel Leban

Executive summary This review describes the successful use of technologies to overproduce and purify recombinant enzymes from trees with the aim of solving their 3D structures and identifying their molecular interactions either with other proteins or with potential substrates. Currently only $\mathrm{ca}$ a dozen of tree genomes have been annotated and released including six forest species, but this will change rapidly with the oncoming release of the chestnut and oak genomes notably. The availability of additional genomes will open the way to identifying the function of a large number of orphan gene products, one of the ways to characterize these functions being to produce and analyze the corresponding protein products.
}

J.-P. Jacquot $(\bowtie) \cdot$ J. Couturier $\cdot$ E. Gelhaye $\cdot$ M. Morel-Rouhier . A. Hecker $\cdot$ D. D. Gütle $\cdot$ N. Rouhier

Université de Lorraine, Interactions Arbres - Microorganismes,

UMR1136, 54500 Vandoeuvre-lès-Nancy, France

e-mail: j2p@univ-lorraine.fr

J.-P. Jacquot $\cdot$ J. Couturier $\cdot$ E. Gelhaye $\cdot$ M. Morel-Rouhier $\cdot$

A. Hecker • D. D. Gütle $\cdot$ N. Rouhier

INRA, Interactions Arbres - Microorganismes, UMR1136,

54280 Champenoux, France

C. Didierjean

Université de Lorraine, CRM2, Equipe BioMod, UMR 7036, Faculté

des Sciences et Technologies, BP 70239 ,

54506 Vandoeuvre-lès-Nancy, France
- Aims and methods Modern techniques of genome analysis coupled with recombinant protein technology and massive 3D structural determination of tree proteins should help elucidate the function of many of the proteins encoded by orphan genes. X-ray crystallography and NMR will be the methods of choice for protein structure determination.

- Results In this review, we provide examples illustrating how the above-mentioned techniques improved our understanding of redox regulatory circuits in poplar, the first forest tree species sequenced. We showed that poplar peroxiredoxins use either thioredoxin or glutaredoxin as electron donors to

\footnotetext{
C. Didierjean

CNRS, CRM2, Equipe BioMod, UMR 7036, Faculté des Sciences et

Technologies, BP 70239, 54506 Vandoeuvre-lès-Nancy, France

C. Plomion

INRA, UMR1202, BIOGECO, 33610 Cestas, France

D. D. Gütle

Plant Biotechnology, Faculty of Biology, Universität Freiburg, Schänzlestrasse 1, 79104 Freiburg, Germany

D. D. Gütle

Spemann Graduate School of Biology and Medicine (SGBM), University of Freiburg, Albertstr. 19A, 79104 Freiburg, Germany
} 
reduce hydrogen peroxide. That glutaredoxin could be a reductant was unknown at the time of this discovery even in other biological organisms and was later confirmed notably by the observation that the two genes are fused in some bacteria and by the resolution of the structure of the bacterial hybrid protein. Similarly, genome analysis coupled to in vitro analysis of enzymatic properties led to the discovery that some plant methionine sulfoxide reductases can also use both thioredoxins and glutaredoxins as electron donors. Besides their disulfide reductase activity, it has been demonstrated that some poplar glutaredoxins are also involved in iron-sulfur center biogenesis and assembly. The original 3D structure determination has been made with poplar glutaredoxin $\mathrm{C} 1$ and then confirmed in a variety of other biological organisms including human. Our work also showed that in plants, socalled glutathione peroxidases use thioredoxins and not glutathione as electron donors. This is true for all nonselenocysteine-containing glutathione peroxidases. Finally, connections between the thioredoxin and glutaredoxin systems have been elucidated through the study of atypical poplar thioredoxins.

- Conclusion Altogether, these data illustrate how the combination of genetic engineering and structural biology improves our understanding of biological processes and helps fuel systems biology for trees and other biological species.

Keywords 3D protein structure $\cdot$ Genome sequence .

Glutaredoxin $\cdot$ Redox $\cdot$ Thioredoxin $\cdot$ Poplar

\section{Introduction}

There are currently more than 50 plant genomes sequenced and published (Michael and Jackson 2013; see also: http://en. wikipedia.org/wiki/List_of_sequenced_plant_genomes), and of these, more than ten concern tree species. The majority of those are constituted by fruit trees (peach, plum, pear, sweet orange, clementine, apple, coffee, papaya, and cocoa tree). The first forest tree genome published is Populus trichocarpa (Tuskan et al. 2006) followed by Picea abies (Nystedt et al. 2013), Hevea brasiliensis (Rahman et al. 2013), Picea glauca (Birol et al. 2013), Pinus taeda (Neale et al. 2014), and Eucalyptus grandis (Myburg et al. 2014).

The analysis of the first tree genomes has helped in identifying the total number of genes present in these genomes and also a number of orphan genes that have no counterpart in other biological organisms. A recent estimate of the number of orphan genes in poplar is $44 \%$, a value much higher than the $14 \%$ estimation in Arabidopsis (Guo et al. 2007; Feldmann and Goff 2013). The mechanisms leading to orphan gene emergence have been discussed in a number of biological systems (Wissler et al. 2013). In order to understand the functions and interaction properties of the proteins encoded by these genes (if any), one possibility is to produce the corresponding recombinant proteins. The elucidation of their 3D structures together with molecular docking is one possibility that can be used to reach that understanding. Other techniques as the yeast two-hybrid system screen and coimmunoprecipitation can also help in identifying the potential ligands either metabolites or macromolecules as other proteins, carbohydrates, or lipids. Together with the results of transcriptomic and proteomic experiments, these approaches will help decipher metabolic and regulation networks. We illustrate here the use of genetic engineering and 3D structure determination to describe the redox interaction networks in trees, concentrating on the glutathione/glutaredoxin- (Grx) and thioredoxin- (Trx) dependent pathways in poplar. Most of the enzymes presented are members of the thioredoxin fold class. They share a small thioredoxin domain (consisting of a four-stranded beta sheet surrounded by three alpha helices) to fulfill many molecular functions.

\section{Redox regulation background}

When biological organisms including trees are submitted to stress either abiotic or biotic, a major response is the establishment of an oxidative burst which has to be controlled in order to avoid excessive accumulation of reactive oxygen species and subsequent subcellular damage. A number of antioxidant systems can be found in trees including the thioredoxin and glutaredoxin systems and structural derivatives such as thiol peroxidases (peroxiredoxins (Prx) and glutathione peroxidases $(G p x)$ ) or methionine sulfoxide reductases (Msr). Notably, the thioredoxin-linked systems control the rate and hence yield of photosynthesis but they are also a good defense line against excess oxidants such as $\mathrm{H}_{2} \mathrm{O}_{2}$ (Schürmann and Jacquot 2000; Rouhier et al. 2008). The general positioning of the thioredoxin- or glutaredoxinlinked redox networks in plants is shown in Fig. 1. In this review, we provide a number of examples detailing how poplar has served as a model for understanding redox regulation not only in plants but also in other systems including animal and bacterial cells. We will also indicate how poplar has become a model species for establishing the 3D structures of plant proteins, a field still in infancy.

\section{Poplar thiol peroxidases: peroxiredoxins and "glutathione" peroxidases}

The studies that have been initiated in poplar were initially a follow-up of the previous characterization of a peroxidedetoxifying enzyme called peroxiredoxin or thioredoxin 
Fig. 1 Positioning and major roles of the glutaredoxin- and thioredoxin-linked systems in plants. This figure emphasizes the central position of the glutaredoxin and thioredoxin systems for the cellular redox control in photosynthetic organisms. Abbreviations used are as follows: $G R$ glutathione reductase, $G S H$ glutathione, $T R$ thioredoxin reductases, Grx glutaredoxin, $\operatorname{Tr} x$ Thioredoxin

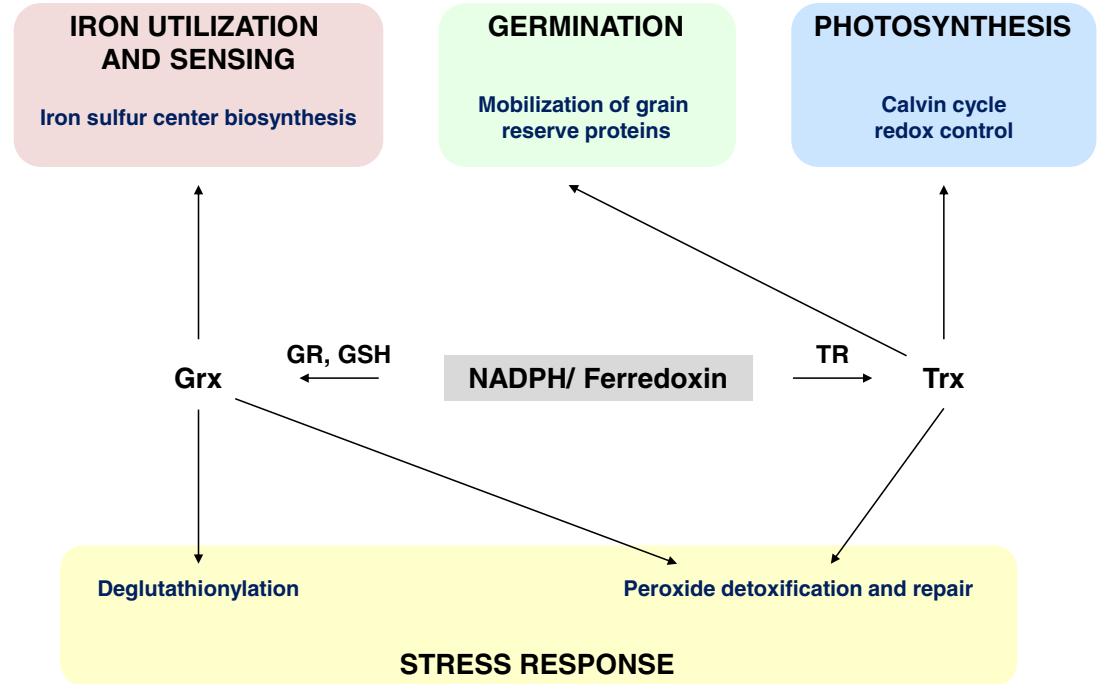

peroxidase (Verdoucq et al. 1999). Peroxiredoxins are very abundant enzymes which rely on a catalytic cysteine residue to attack various organic peroxides (including hydrogen peroxide) with the release of an alcohol-like molecule and water according to the equation:

$\mathrm{ROOH} \rightarrow \mathrm{ROH}+\mathrm{H}_{2} \mathrm{O}$

In the process, the catalytic cysteine residue becomes oxidized into a sulfenic acid which has to be regenerated, the best known regenerating system being the thioredoxin system (NADPH or photoreduced ferredoxin relayed by a thioredoxin reductase and thioredoxin itself). Including glutathione peroxidases, there are five classes of thioredoxin peroxidases in plants based on their amino acid sequence and oligomerization state (Rouhier and Jacquot 2005). Several of them are solely dependent on thioredoxin for their regeneration (Rouhier et al. 2004b; Navrot et al. 2006), but surprisingly our initial data which concerned a specific class called atypical type II peroxiredoxin (later referred to as poplar PrxIIB) indicated that they could be regenerated equally well by thioredoxin and glutaredoxin (Rouhier et al. 2001, 2002a). That glutaredoxins could be an alternate reducing system to atypical type II peroxiredoxins was unknown at that time in other biological organisms. We could in subsequent experiments determine that poplar type II peroxiredoxins are present in several cellular compartments and in particular in the cytosol, mitochondria, and plastids (Gama et al. 2007, 2008). The 3D structure of the cytosolic poplar Prx IIB has been solved both by X-ray crystallography and NMR revealing molecular aspects of its organization, catalytic and regeneration mechanisms (Echalier et al. 2005; Noguera-Mazon et al. 2006). A nice confirmation that glutaredoxin could indeed be a physiological reductant for type II Prx was the detection of hybrid genes in several bacteria. As for thioredoxin reductase-thioredoxin gene fusions observed in some mycobacteria as Mycobacterium leprae (Jacquot et al. 2009), Prx and Grx genes can be associated in operons and even fused in some species as Haemophilus influenzae and Neisseria meningitidis resulting in the generation of a hybrid enzyme (Kim et al. 2003; Rouhier and Jacquot 2003). Based on the sequence of the linker peptide between the two domains (Grx and Prx), we were then able in "fun experiments" to construct functional Prx-Grx and Prx-Trx fusion proteins made with poplar sequences (Rouhier et al. 2006b). We have also studied deeply another variety of peroxiredoxin from poplar called peroxiredoxin Q (Prx Q in plants or BCP in bacteria) (Rouhier et al. 2004b). Prx Q is exclusively chloroplastic and the poplar enzyme is brought back to the reduced form by the thioredoxin system but not via the glutaredoxin system unlike type II Prx. Prx Q expression is modified when poplar leaves are infected by the rust fungus Melampsora larici-populina. We could not get a 3D structure of poplar Prx Q but we have been later able to isolate and characterize structurally a hybrid enzyme from Thermotoga maritima which contains a Prx Q-like module linked to a nitroreductase domain (Couturier et al. 2013b). Interestingly in T. maritima, the hybrid enzyme is reduced by an unusual reduction system composed of thioredoxin reductase and glutaredoxin-like enzymes, indicating that glutaredoxins can be donors in other biological systems than poplar. In non-photosynthetic organisms, another line of defense against excessive peroxide generation is constituted by Gpxs. Those enzymes employ similar catalytic mechanisms and sulfenic acid chemistry as Prxs. There are several classes of Gpxs in mammals 
including selenocysteine-containing enzymes which are present only in algae but not in land plants, the Gpxs of which contain cysteines instead of selenocysteines. For the selenoenzymes, the selenenic acid is normally brought back to the thiol state via reduced glutathione. Interestingly, we have observed using the poplar model that plant Gpxs are present in different subcellular compartments but also that they differ from their mammalian selenoenzyme counterparts in using thioredoxin but not glutathione for their regeneration. Whereas it is in principle possible for GSH to reduce sulfenic acids, the presence of a resolving cysteine in plant Gpxs leads to the formation on an intramolecular disulfide which can only be reduced by Trxs. In this respect, cysteine-containing Gpxs can be considered as thioredoxin peroxidases or peroxiredoxins. Indeed, the structural determination of poplar Gpx5 indicated that it has a fold similar to peroxiredoxins, an observation that was not clear from the examination of amino acid sequences (Navrot et al. 2006; Koh et al. 2007). Figure 2 illustrates this structural convergence between type II Prx and so-called plant Gpx (panels a, b). The monomer organization is similar, based on the thioredoxin model plus a helix-beta strand insertion between the second helix and the second $\beta$-strand of the Trx fold and a $\beta$ hairpin $\mathrm{N}$-terminal extension. Interestingly, plant Gpx can reduce not only hydroperoxides but also peroxynitrites (Selles et al. 2012). In conclusion, this set of experiments has allowed us to determine that unlike their mammalian counterparts, plant Gpxs do not rely on glutathione but rather on the thioredoxin system for their functioning and regeneration. The peroxiredoxin and Gpx "stories" have also provided one of the examples of the interchangeability between the thioredoxin and glutaredoxin pathways with regard to peroxide detoxification.

\section{Poplar methionine sulfoxide reductases}

Another example of a repair enzyme using sulfenic acid chemistry is the methionine sulfoxide reductase. Oxidative stress can indeed induce the oxidation of the side chain of methionine residues resulting in methionine sulfoxide generation. Depending on the stereochemistry, two types of Msrs can repair this oxidative modification: MsrA and MsrB. MsrA has been characterized in poplar and its $3 \mathrm{D}$ structure deciphered. Unlike Prx whose structure is based on the thioredoxin fold, MsrA exhibits a unique alpha/beta architecture. Figure $2 \mathrm{c}$ shows the structure of the subunit of MsrA together with the position of the cysteines involved in catalysis. For catalysis, the two poplar MsrAs characterized rely on a three cysteine mechanism, the order of the cysteine involvement being different from the Escherichia coli enzyme
Fig. 2 Selected structures of poplar enzymes. In all these structures, $\beta$ strands are shown in blue, $\alpha$-helices are in red, and connecting loops are in purple. a Cartoon representation of the overall fold of the dimeric Prx IIB (PDB number, 1TP9). b Cartoon representation of the overall fold of the dimeric Gpx5 in the reduced form (PDB number, 2P5Q). Note that, in the oxidized form, the formation of an intramolecular disulfide bond between Cys44 and Cys92 induces a large conformational rearrangement leading in particular to the complete unwinding of the $\alpha 1$ helix. By comparing both structures, you could note the similar architecture of the monomers and the characteristic double $\beta$-strand external to the central pleated $\beta$-sheet. $\mathbf{c}$ Cartoon representation of the overall fold of the plastidial methionine sulfoxide reductase A (PDB number, 2J89). The structure of the monomer in the reduced form is shown here. The positions of the sulfur atoms of the important cysteine residues are indicated by yellow spheres. Site-directed mutagenesis experiments coupled to activity assays indicated that the catalytic Cys46 forms a disulfide with Cys202 before its subsequent reduction by Cys196. It is clear that considerable conformational rearrangements are needed to bring the sulfur atoms close enough to form these disulfides. This may explain why we have been unable to get the 3D structure of oxidized forms. d Cartoon representation of the overall fold of the monomeric thioredoxin $\mathrm{h} 4$ under two different oxidized forms (PDB numbers 3D21, 3D22). The sulfur atoms of the cysteine residues of the disulfide bonds are shown in yellow spheres. Left panel, disulfide bond between Cys58 and Cys61; right panel, disulfide bond between Cys4 and Cys58. Lacking residues (7-15) are shown in an imaginary gray dashed loop for a better overview of the right panel structure. e, f Structural comparison of Grx $\mathrm{C} 1$ and Grx $\mathrm{C} 4$ dimers. In the Grx $\mathrm{C} 1$ structure, there is one homodimer containing a [2Fe-2S] ISC plus two additional monomers symmetrically positioned but bearing no ISC. GSH indicates an external glutathione molecule (shown in stick) and GS glutathione molecule covalently linked to the $\mathrm{Fe}_{2} \mathrm{~S}_{2}$ center. Sulfur and iron atoms are represented, respectively, as yellow and red spheres. Grx $\mathrm{C} 4$ makes a homodimer with no ISC. The PDB number of Grx C1 is 2E7P, whereas no coordinates were deposited for Grx C4

(Rouhier et al. 2007a). Initially for poplar MsrA, the most efficient reductant system was found to be the thioredoxin system. However, it was found later that, in Gracilaria gracilis, MsrA and Grx are linked in a Grx-Grx-MsrA hybrid enzyme, a situation reminiscent of the earlier identification of Prx-Grx fusions. Additionally, subsequent experiments have shown that Msrs of the two types (A and B) including poplar MsrA are also efficiently regenerated by the glutaredoxin system (Vieira dos Santos et al. 2007; Tarrago et al. 2009; Couturier et al. 2012). Overall, these data provide further evidence concerning the interchangeability of the two reduction systems.

\section{Poplar thioredoxins}

Additional data connecting the thioredoxin and glutaredoxin systems were provided by the thorough study of poplar 
a

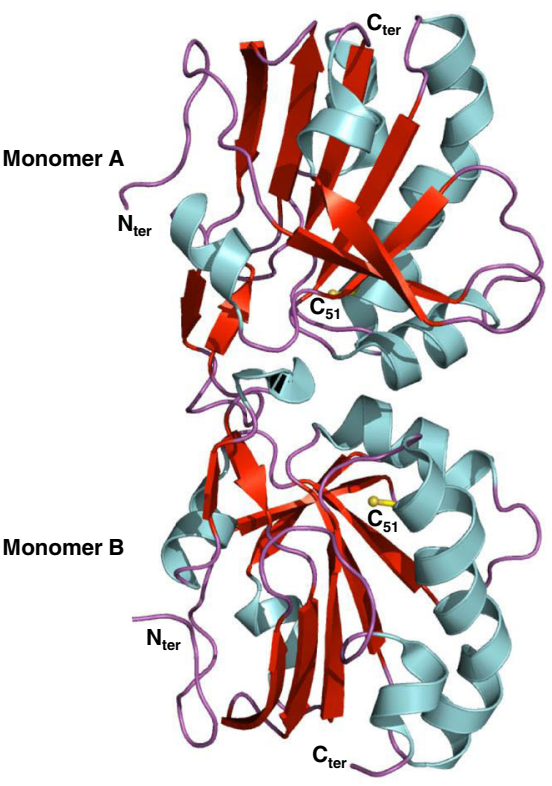

c

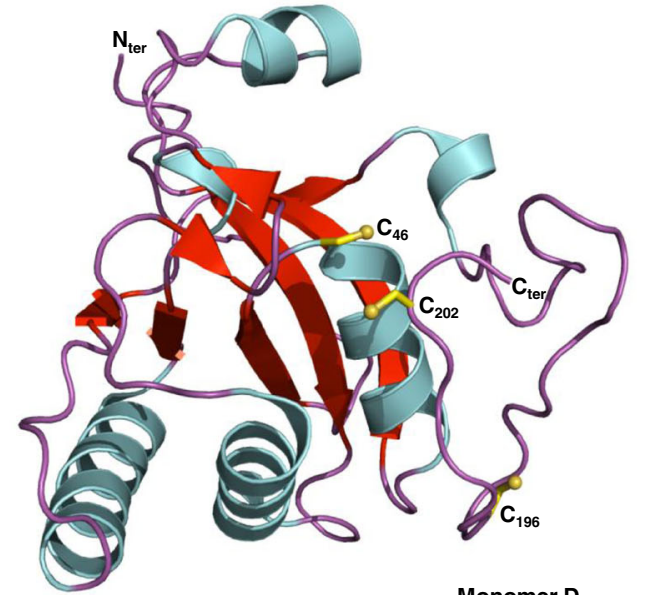

e

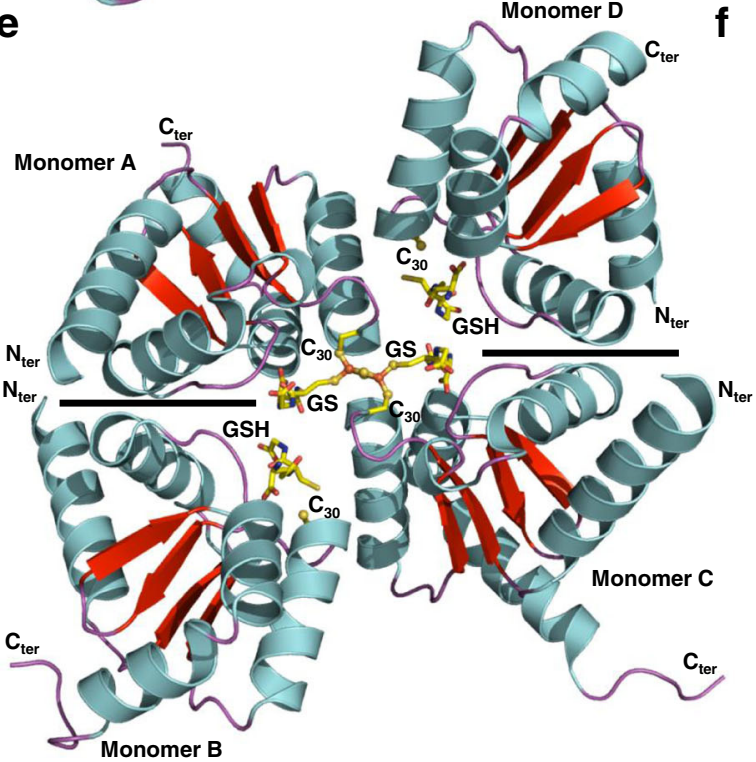

b

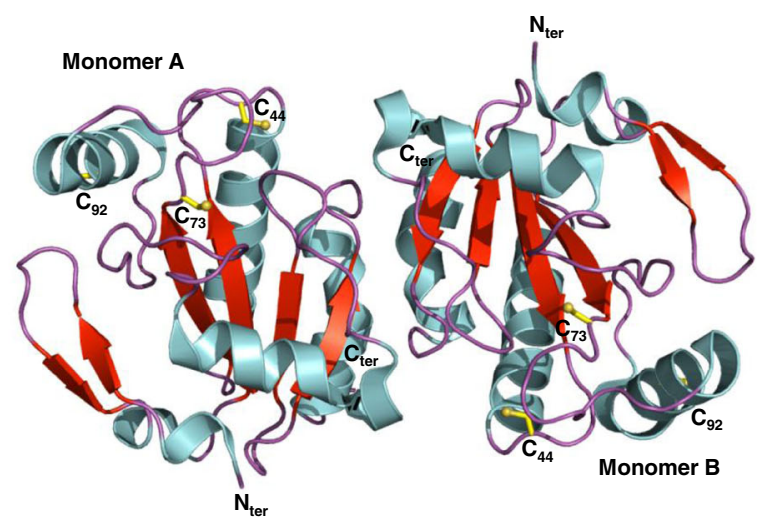

d

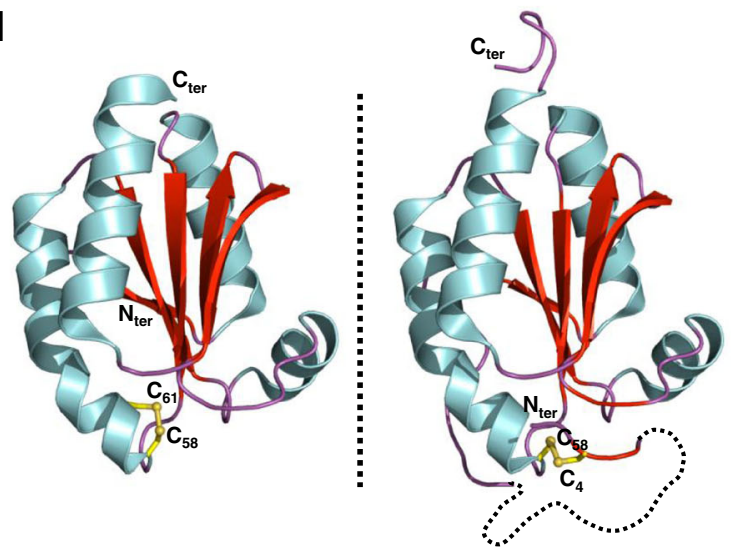

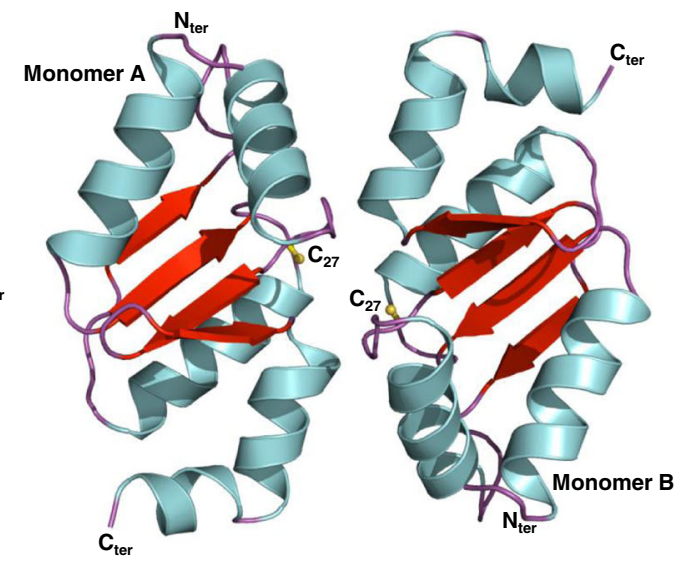

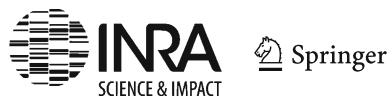


thioredoxins. We first set out to describe the first structure of an active site variant (CPPC instead of CGPC) in poplar Trxh1 (Coudevylle et al. 2004, 2005). The NMR structural analysis revealed that changing the glycine residue of the active site into a proline has very moderate effect on the structure (Menchise et al. 2001), although based on yeast complementation, CPPC containing thioredoxins are less active in sulfate reduction but more efficient for protection against $\mathrm{H}_{2} \mathrm{O}_{2}$ than their CGPC counterparts (Bréhelín et al. 2000). Further characterization of poplar thioredoxins included the study of poplar Trxh3 (Gelhaye et al. 2003b) and also showed that the Trxh2 isoform is located in mitochondria where it serves to regulate alternative oxidase and the mitochondrial electron flow (Gelhaye et al. 2004). Incidentally, this was the first clear demonstration of the presence of thioredoxin $\mathrm{h}$ in plant mitochondria. A very interesting piece of information arose when studying poplar Trx h4. This protein possesses a classical active site (CGPC) but has the unique characteristic to contain a conserved cysteine near the N-terminus at position 4 (Gelhaye et al. 2003a). Through sitedirected mutagenesis and structural determination, we have shown that this was related to an unusual three cysteine mechanism where two successive and different disulfides are formed upon catalysis, one of them involving Cys4. Remarkably, the regeneration system of Trx h4 is the glutaredoxin system and not the NAPDHthioredoxin reductase system (Koh et al. 2008). Figure $2 \mathrm{~d}$ shows the structure of poplar Trx h4 with its characteristic pleated $\beta$-sheet surrounded by $\alpha$ helices found in all thioredoxins. Unlike in non-photosynthetic organisms, there are in fact a large number of thioredoxin genes in plants and the situation is similar in poplar (Gelhaye et al. 2005; Chibani et al. 2009). One of the newly discovered thioredoxins, $\operatorname{Trx} \mathrm{z}$, is located in plastids and reduced by the ferredoxin-thioredoxin reductase (FTR) (Chibani et al. 2011). Several of the thioredoxin genes code for proteins with highly unusual active sites. We showed quite recently that in contrast with their classification based on amino acid sequence similarities, poplar Trx-like2.1 and Trx-lilium2.2 are regenerated in vitro either by the NADPH-thioredoxin reductase system or by glutathione but not the FTR system (Chibani et al. 2012). As a consequence, since these two thioredoxins are plastidial, their likely in vivo reducing system is glutathione, thus resembling glutaredoxins. Consistently, Trx-like2.1 was found to be effective in MsrB1 and PrxIIE regeneration, two known Grx target enzymes. Altogether, these results further exemplify the need to back up phylogenetic studies with "wet lab" biochemistry. A similar need was apparent from the wrong classification of plant "glutathione" peroxidases which turned out to be thioredoxin peroxidases as detailed previously. Concerning our own redox research, these data also reinforce the notion of thioredoxin-glutaredoxin cross talk already previously mentioned. To conclude on the past studies on poplar thioredoxins on a more physiological note, we have very recently obtained evidence that thioredoxin $\mathrm{h} 1$ is involved in the gravitropism response being itself localized in the amyloplasts of the endoderm, a localization of high interest for gravitropism signal perception (Azri et al. 2013). Overall, the international recognition of these studies on poplar in a competitive field (including research groups in medicine and other areas of biology) is apparent in a paper by Perez-Jimenez et al. (2009) where two poplar thioredoxin h were selected in a study detailing thioredoxin catalysis at the single molecule and atomic level.

\section{Poplar glutaredoxins}

Another section of the redox field where we have made significant contributions is the study of glutaredoxins, the initial breakthrough papers having been made with poplar Grxs. As observed for Trxs, Grxs make an extended phylogenetic family in photosynthetic organisms including poplar but conversely the number of Grx genes is much reduced in bacteria or mammals (Rouhier et al. 2004a, 2006a; Couturier et al. 2009a, 2013a). Overall, there are three major groups in land plants with active sites in the form of CxxC (class I), CGFS (class II), and $\mathrm{CCxC} / \mathrm{S}$ (class III). Class III Grxs are present solely in land plants and play a role in flower development ( $\mathrm{Li}$ et al. 2009). From genomic and phylogenetic analyses, a fourth Grx class is also present in land plants but whether they exhibit glutathione-dependent reductase activity awaits confirmation (Couturier et al. 2009a). Additional classes formed by fusion enzymes are found in lower eukaryotes and prokaryotes. The Grx studies were initiated with poplar Grx C4, a class I member with a "classical" CYPC active site. The corresponding protein was produced in a soluble form by genetic engineering but only after optimization of its DNA sequence and its biochemical properties studied. It did not turn out to be different from other classical Grxs (d'Ambrosio et al. 2003; Rouhier et al. 2002b, 2003). On the other hand, the characterization of poplar Grx C1 (class I, CGYC active site) led to surprising results as the recombinant protein partitioned between an apo monomeric form and 
a holo dimeric form. Very interestingly, the holo form was shown to contain an iron sulfur center (ISC) of the $\mathrm{Fe}_{2} \mathrm{~S}_{2}$ type (Feng et al. 2005, 2006; Rouhier et al. 2007b). NMR-linked structural determination of Grx C4 which does not normally assemble such holo structures indicated nevertheless that the protein makes homodimers in solution with the active sites facing one another (Noguera et al. 2005). Figures 2e, f show dimers of Grx C1 and Grx C4, with the ISC present in the former but not the latter. A thorough comparison of the structures of both Grxs revealed that the Pro residue present between the two Cys of the disulfide is probably too bulky to allow the formation of the ISC in Grx C4. In agreement with this observation, the $\mathrm{P}$ to $\mathrm{G}$ mutation in Grx $\mathrm{C} 4$ allows the protein to incorporate an ISC into a homodimer, and the reverse mutation in Grx $\mathrm{C} 1$ abolishes that property (Rouhier et al. 2007b). A crucial observation in Grx $\mathrm{C} 1$ is that two of the Fe-S ligands are external glutathione molecules, a situation also encountered in a number of non-photosynthetic homologs (Rouhier et al. 2008). Incidentally, these data complexify the bioinformatics prediction of sequences able to bind an ISC. Normally, they should contain four cysteines or a similar number of cysteine and histidine ligand residues, but in the permissive glutaredoxins, only one cysteine per monomer is sufficient (Selles et al. 2009). The structural study of class I poplar Grx S12 and also of Arabidopsis thaliana Grx C5 has added more to our understanding concerning the sequence requirements permissive for ISC binding (Couturier et al. 2009b, 2011). The observation that Grxs from class II can bind ISC has shed new light on a completely different research area, the biosynthesis of ISC. Indeed, it was known that in yeast the mitochondrial Grx5 (class II, CGFS active site) is required for Fe-S cluster biogenesis but it was not known why (Rodríguez-Manzaneque et al. 2002). Work performed with CGFS Grxs from poplar or Arabidopsis has demonstrated that they also ligate ISC. In addition, they can very efficiently transfer these centers to acceptor proteins as apo ferredoxin (Bandyopadhyay et al. 2008; Rouhier et al. 2010). Overall, these very original contributions made with poplar proteins support an additional role for glutaredoxins in $\mathrm{Fe}-\mathrm{S}$ protein assembly, separate from the classical reductase activity.

While progress has been remarkable on class I and II members, we know little about the biochemical and structural properties of class III Grxs. Indeed, they are notoriously difficult to work with owing to insolubility problems perhaps linked to the very hydrophobic Cterminus of the protein. Nevertheless, we have made a number of constructs using poplar Grx $\mathrm{C} 1$ and Grx $\mathrm{C} 4$ as templates in which we have introduced active site signatures (CCMC and CCMS) present in class III Grxs. In agreement with the structural predictions made from earlier work on Grx C1 and C4, the engineered Grxs bind $\mathrm{Fe}-\mathrm{S}$ centers and possess reductase activity in the monomeric form (Couturier et al. 2010). Whether these data reflect specific physiological functions awaits further characterization.

\section{Biochemical and structural studies of redox enzymes in progress}

Having isolated to homogeneity a number of poplar thioredoxins and glutaredoxins has allowed us to trap their potential targets. This was performed by genetic engineering and modifying the second cysteine of the active sites into serines which in effect prevents the backup reaction and allows trapping the target disulfide-linked to the redoxin. Using this technology, we have identified $c a$ 100 Grx targets suggesting that redox post-translational modifications control a large number of cellular processes. A carbonic anhydrase was further characterized (Rouhier et al. 2005). Likewise, the use of a mutated poplar thioredoxin $\mathrm{h}$ led to the identification of more than 50 Trx-linked proteins in the mitochondria (Balmer et al. 2004). The structural and regulatory properties of those potential targets are still largely unknown even though redox regulation in mitochondria was reported for 2-oxoaciddehydrogenase complexes (Bunik et al. 1999).

There are a large number of glutathione- $S$-transferases (GST) genes in photosynthetic organisms and especially in poplar (Lan et al. 2009; Lallement et al. 2014a). These proteins are involved mainly in cellular detoxification. Some of these proteins possess a catalytic cysteine and they are functionally similar to Grxs. Three GSTs of the lambda type (GSTL1 to L3) have been recently characterized until the molecular level. The proteins are monomeric and they bind glutathionylated substrates for deglutathionylation reactions (Lallement et al. 2014b). Overall, this study strengthened the proposal that GSTLs are involved in the management of secondary metabolites via their redox properties. Additional poplar GSTs from different classes are currently being studied.

We have mentioned earlier the existence of thioredoxinlike proteins in poplar (like2- and lilium-types especially), indicating that these proteins functionally behave as glutaredoxins. From this observation, it becomes of high interest to elucidate what in their structure makes them 
glutaredoxin-like from a catalytic point of view. As a matter of fact, several of these structures are being solved presently and we should be able to answer this question soon.

Another area where we are currently active concerns the regulatory enzymes of the Benson-Calvin cycle and especially the phosphatases, fructose-1,6-bisphosphatase (FBPase), and sedoheptulose-1,7-bisphosphatase (SBPase). It is known that both enzymes are redoxregulated but the relationship between them is still unclear at the molecular level. Although we know precisely the structure and regulatory properties of pea FBPase, little is known about the structure-function relationship of SBPase (Jacquot et al. 1995; Chiadmi et al. 1999). In a first series of experiments, we have produced the corresponding recombinant proteins from poplar and Chlamydomonas reinhardtii but the enzymes turned out not to be sufficiently stable and rather rapidly denatured. We have then turned to another model Physcomitrella patens (see companion paper by Müller et al. this issue) from where we could produce stable FBPase and SBPase as recombinant proteins. The biochemical and structural properties of both proteins are currently under investigation. The Physcomitrella patens model is also currently being used to create mutants of the ferredoxin-thioredoxin system using site-directed mutagenesis and gene replacement for the catalytic subunit of FTR.

Another area of current excitement is the involvement of class II Grxs in ISC biosynthesis. In three recent papers, the structures of poplar Grx S14 were solved and its Fe-S cluster transfer capacity described (Wang et al. 2011, 2012, 2014). Current emphasis is made on the interactions between class II Grxs and BolA proteins or similar components such as SufE1 protein (Couturier et al. 2014; Roret et al. 2014). A last domain of interest that is being investigated concerns the link between redox and biotic stress. Indeed when poplar leaves are infected by rust there is a very active exchange of information including the release of small secreted proteins (SSP) by both interaction partners. These SSP very often possess unusually high cysteine contents with the possibility to make several disulfides. We are currently studying the properties of some corresponding recombinant proteins up to the 3D molecular level. Interestingly, many of these SSPs would qualify as orphan gene products.

\section{Census of tree protein 3D structures}

As explained above, the availability of gene models from fully sequenced genomes is extremely helpful and even required for the development of high throughput structural biology with the aim of deciphering tree protein structures. In the pdb database, the structures are listed with a link to their botanical classification and unfortunately the item tree is not present. So making a census of the present tree protein structures is not an easy task. Also the definition of a tree is not so clear; for example, we chose not to define banana (overall nine protein structures available of three different proteins) and coconut (one structure in pdb) as trees as various botanical considerations indicate they should not be labeled as such. Another example is Vitis vinifera (overall 20 protein structures nearly all of them describing oxidoreductases of the secondary metabolism) which we chose not to include as a tree although it is an organism which contains lignin but it does not have the stance of a tree. Tables 1 and 2 provide the current data concerning protein structures from forest and non-forest trees, respectively. Using a very empirical approach (looking systematically for most well-known tree species), we have found 141 protein structures belonging to forest species including $H$. brasiliensis and 33 structures to non-forest species (including fruit trees but also plantation trees as coffee). The non-forest tree protein structures describe $\mathrm{ca} 14$ different proteins from five different botanical families. The known forest tree protein structures belong to seven genera (Betulaceae, Cesalpinaceae, Euphorbiaceae, Fabaceae, Salicaceae, Taxaceae, and Pinaceae) and they describe $\mathrm{ca} 36$ different protein structures. A large number of these structures (18) describe a single pollen allergen of birch, the BET V allergen, and a similar number (17) a hydroxynitryle lyase from Hevea. Overall, nearly half of the forest tree structures describe poplar proteins illustrating how genome sequencing influences downstream the structural field (poplar was the first genome tree sequenced and fully annotated). Overall, 19 of the poplar structures describe a single protein plastocyanin either from NMR or crystallographic data in complex with a variety of ligands, one of the structures describing plastocyanin in complex with cytochrome f. In reality, the effort concerning plastocyanin started well before the genome sequence of poplar became available. Our own contribution to the structural field has resulted in 17 structures describing 11 different poplar proteins in various states solved either by NMR or X-ray crystallography. They are marked with a star in Table 1. It now seems clear that poplar is bound to become a model organism for structural biology especially when coupled to molecular biology allowing the production of recombinant proteins. Still it is remarkable that the first plastocyanin structure was obtained with the poplar protein well before the advent of all those molecular techniques (Guss and Freeman 1983). To conclude on those aspects of structural biology, it should be mentioned that poplar is and will most likely become the 
Table 1 Known forest tree protein structures

\begin{tabular}{|c|c|c|c|}
\hline PDB code & Family & Source & Enzyme/protein \\
\hline $1 \mathrm{~B} 6 \mathrm{~F}$ & Betulaceae & Betula pendula (birch) & BET V 1 allergen \\
\hline 1BTV & Betulaceae & Betula pendula (birch) & BET V 1 allergen \\
\hline 1BV1 & Betulaceae & Betula pendula (birch) & BET V 1 allergen \\
\hline 1FM4 & Betulaceae & Betula pendula (birch) & BET V 1 allergen \\
\hline $1 \mathrm{LLT}$ & Betulaceae & Betula pendula (birch) & BET V 1 allergen \\
\hline 1QMR & Betulaceae & Betula pendula (birch) & BET V 1 allergen \\
\hline $4 \mathrm{~A} 80$ & Betulaceae & Betula pendula (birch) & BET V 1 allergen \\
\hline $4 \mathrm{~A} 81$ & Betulaceae & Betula pendula (birch) & BET V 1 allergen \\
\hline $4 \mathrm{~A} 83$ & Betulaceae & Betula pendula (birch) & BET V 1 allergen \\
\hline $4 \mathrm{~A} 84$ & Betulaceae & Betula pendula (birch) & BET V 1 allergen \\
\hline $4 \mathrm{~A} 85$ & Betulaceae & Betula pendula (birch) & BET V 1 allergen \\
\hline $4 \mathrm{~A} 86$ & Betulaceae & Betula pendula (birch) & BET V 1 allergen \\
\hline $4 \mathrm{~A} 87$ & Betulaceae & Betula pendula (birch) & BET V 1 allergen \\
\hline $4 \mathrm{~A} 88$ & Betulaceae & Betula pendula (birch) & BET V 1 allergen \\
\hline $4 \mathrm{~A} 8 \mathrm{G}$ & Betulaceae & Betula pendula (birch) & BET V 1 allergen \\
\hline $4 \mathrm{~A} 8 \mathrm{U}$ & Betulaceae & Betula pendula (birch) & BET V 1 allergen \\
\hline $4 \mathrm{~A} 8 \mathrm{~V}$ & Betulaceae & Betula pendula (birch) & BET V 1 allergen \\
\hline 4B9R & Betulaceae & Betula pendula (birch) & BET V 1 allergen \\
\hline 4BK6 & Betulaceae & Betula pendula (birch) & BET V 1 allergen \\
\hline $4 \mathrm{BK} 7$ & Betulaceae & Betula pendula (birch) & BET V 1 allergen \\
\hline $4 \mathrm{BKC}$ & Betulaceae & Betula pendula (birch) & BET V 1 allergen \\
\hline 4BKD & Betulaceae & Betula pendula (birch) & BET V 1 allergen \\
\hline 4BTZ & Betulaceae & Betula pendula (birch) & BET V 1 allergen \\
\hline 1H4B & Betulaceae & Betula pendula (birch) & BET V 4 allergen \\
\hline 1CQA & Betulaceae & Betula pendula (birch) & Profilin \\
\hline $1 \mathrm{R} 8 \mathrm{~N}$ & Caesalpinaceae & Delonix regia & Kunitz trypsin inhibitor \\
\hline 3QQQ & Cannabaceae & Trema tomentosa & Plant hemoglobin \\
\hline 1PXZ & Cupressaceae & Cedar & Allergen \\
\hline 1QYD & Cupressaceae & Thuya & Pinoresinol reductase \\
\hline 1P9G & Eucommiaceae & Eucommia ulmoides & Antifungal peptide \\
\hline $1 \mathrm{P} 9 \mathrm{Z}$ & Eucommiaceae & Eucommia ulmoides & Antifungal peptide \\
\hline 4MPI & Euphorbiaceae & Hevea & $\begin{array}{l}\text { Chitin-binding module of } \\
\text { a chitinase-like protein }\end{array}$ \\
\hline 4HPG & Euphorbiaceae & Hevea & Glycosylated glucanase \\
\hline 4IIS & Euphorbiaceae & Hevea & Glycosylated glucanase \\
\hline 1HVQ & Euphorbiaceae & Hevea & Hevamin A \\
\hline $1 \mathrm{LLO}$ & Euphorbiaceae & Hevea & Hevamin A \\
\hline $2 \mathrm{HVM}$ & Euphorbiaceae & Hevea & Hevamin A \\
\hline $1 \mathrm{KQY}$ & Euphorbiaceae & Hevea & Hevamin mutant \\
\hline $1 \mathrm{KQZ}$ & Euphorbiaceae & Hevea & Hevamin mutant \\
\hline $1 \mathrm{KR} 0$ & Euphorbiaceae & Hevea & Hevamin mutant \\
\hline $1 \mathrm{KR} 1$ & Euphorbiaceae & Hevea & Hevamin mutant \\
\hline $1 \mathrm{HEV}$ & Euphorbiaceae & Hevea & Hevein \\
\hline 1QB9 & Euphorbiaceae & Hevea & Hevein \\
\hline $1 \mathrm{~T} 0 \mathrm{~W}$ & Euphorbiaceae & Hevea & Hevein \\
\hline $1 \mathrm{WKX}$ & Euphorbiaceae & Hevea & Hevein \\
\hline 4YAS & Euphorbiaceae & Hevea & Hydroxy nitryle lyase \\
\hline 5YAS & Euphorbiaceae & Hevea & Hydroxy nitryle lyase \\
\hline 6YAS & Euphorbiaceae & Hevea & Hydroxy nitryle lyase \\
\hline 7YAS & Euphorbiaceae & Hevea & Hydroxy nitryle lyase \\
\hline
\end{tabular}

${ }^{a}$ Indicates the structures deposited by the authors of this paper

\author{
BET V 1 allergen \\ BET V 1 allergen \\ BET V 1 allergen \\ BET V 1 allergen \\ BET V 1 allergen \\ BET V 1 allergen \\ BET V 1 allergen \\ BET V 1 allergen \\ BET V 1 allergen \\ BET V 1 allergen \\ BET V 1 allergen \\ BET V 1 allergen \\ BET V 1 allergen \\ BET V 1 allergen \\ BET V 1 allergen \\ BET V 1 allergen \\ BET V 4 allergen \\ Profilin \\ Plant hemoglobin \\ Allergen \\ Pinoresinol reductase \\ Antifungal peptide \\ Antifungal peptide \\ Chitin-binding module of \\ a chitinase-like protein \\ Glycosylated glucanase \\ Glycosylated glucanase \\ Hevamin A \\ Hevamin A \\ Hevamin A \\ Hevamin mutan \\ Hevamin mutan \\ Hevamin mutan \\ Hevamin mutan \\ Hevein \\ Hydroxy nitryle \\ Hydroxy nitryle lyase
}


Table 1 (continued)

\begin{tabular}{|c|c|c|c|}
\hline PDB code & Family & Source & Enzyme/protein \\
\hline 1QJ4 & Euphorbiaceae & Hevea & Hydroxynitryle lyase \\
\hline $1 \mathrm{SC} 9$ & Euphorbiaceae & Hevea & Hydroxynitryle lyase \\
\hline 1SCI & Euphorbiaceae & Hevea & Hydroxynitryle lyase \\
\hline $1 \mathrm{SCK}$ & Euphorbiaceae & Hevea & Hydroxynitryle lyase \\
\hline 1SCQ & Euphorbiaceae & Hevea & Hydroxynitryle lyase \\
\hline 1YAS & Euphorbiaceae & Hevea & Hydroxynitryle lyase \\
\hline 1YB6 & Euphorbiaceae & Hevea & Hydroxynitryle lyase \\
\hline 1YB7 & Euphorbiaceae & Hevea & Hydroxynitryle lyase \\
\hline $2 \mathrm{G} 4 \mathrm{~L}$ & Euphorbiaceae & Hevea & Hydroxynitryle lyase \\
\hline 2YAS & Euphorbiaceae & Hevea & Hydroxynitryle lyase \\
\hline $3 \mathrm{C} 6 \mathrm{X}$ & Euphorbiaceae & Hevea & Hydroxynitryle lyase \\
\hline $3 \mathrm{C} 6 \mathrm{Y}$ & Euphorbiaceae & Hevea & Hydroxynitryle lyase \\
\hline $3 \mathrm{C} 6 \mathrm{Z}$ & Euphorbiaceae & Hevea & Hydroxynitryle lyase \\
\hline $3 \mathrm{C} 70$ & Euphorbiaceae & Hevea & Hydroxynitryle lyase \\
\hline 3YAS & Euphorbiaceae & Hevea & Hydroxynitryle lyase \\
\hline $1 \mathrm{G} 5 \mathrm{U}$ & Euphorbiaceae & Hevea & Latex profilin \\
\hline $1 \mathrm{FNY}$ & Fabaceae & Robinia & Lectin \\
\hline $1 \mathrm{FNZ}$ & Fabaceae & Robinia & Lectin \\
\hline 2VLC & Laraceae & $\begin{array}{l}\text { Cinnamomum camphora } \\
\text { (camphor) }\end{array}$ & $\begin{array}{l}\text { Cinnamomin (ribosome } \\
\text { inactivating protein) }\end{array}$ \\
\hline $2 \mathrm{LVF}$ & Lecythidoideae & $\begin{array}{l}\text { Bertholletia excelsa } \\
\text { (Brazil nut) }\end{array}$ & Allergen \\
\hline $1 J 4 S$ & Moraceae & Artocarpus & Artocarpin \\
\hline $1 \mathrm{~J} 4 \mathrm{~T}$ & Moraceae & Artocarpus & Artocarpin \\
\hline $1 \mathrm{~J} 4 \mathrm{U}$ & Moraceae & Artocarpus & Artocarpin \\
\hline $1 \mathrm{VBO}$ & Moraceae & Artocarpus & Artocarpin \\
\hline $1 \mathrm{VBP}$ & Moraceae & Artocarpus & Artocarpin \\
\hline $1 \mathrm{JAC}$ & Moraceae & Artocarpus & Jacalin \\
\hline $1 \mathrm{WS} 4$ & Moraceae & Artocarpus & Jacalin \\
\hline 1WS5 & Moraceae & Artocarpus & Jacalin \\
\hline $3 \mathrm{P} 8 \mathrm{~S}$ & Moraceae & Artocarpus & Jacalin \\
\hline 1KU8 & Moraceae & Artocarpus & Jacalin (lectin) \\
\hline $1 \mathrm{KUJ}$ & Moraceae & Artocarpus & Jacalin (lectin) \\
\hline $1 \mathrm{M} 26$ & Moraceae & Artocarpus & Jacalin (lectin) \\
\hline 1PXD & Moraceae & Artocarpus & Jacalin (lectin) \\
\hline 1UGW & Moraceae & Artocarpus & Jacalin (lectin) \\
\hline 1UGX & Moraceae & Artocarpus & Jacalin (lectin) \\
\hline $1 \mathrm{UGY}$ & Moraceae & Artocarpus & Jacalin (lectin) \\
\hline $1 \mathrm{UH} 0$ & Moraceae & Artocarpus & Jacalin (lectin) \\
\hline 1UH1 & Moraceae & Artocarpus & Jacalin (lectin) \\
\hline 1TOQ & Moraceae & Artocarpus & Lectin \\
\hline $1 \mathrm{TP} 8$ & Moraceae & Artocarpus & Lectin \\
\hline $4 \mathrm{AK} 4$ & Moraceae & Artocarpus & Lectin \\
\hline $4 \mathrm{AKB}$ & Moraceae & Artocarpus & Lectin \\
\hline $4 \mathrm{AKC}$ & Moraceae & Artocarpus & Lectin \\
\hline $4 \mathrm{AKD}$ & Moraceae & Artocarpus & Lectin \\
\hline $4 \mathrm{CUO}$ & Moraceae & Ficus bengalensis & Banyan peroxidase \\
\hline $1 \mathrm{JOT}$ & Moraceae & Maclura pomifera & Agglutinin \\
\hline $3 \mathrm{LLY}$ & Moraceae & Maclura pomifera & Agglutinin \\
\hline $3 \mathrm{LLZ}$ & Moraceae & Maclura pomifera & Agglutinin \\
\hline
\end{tabular}


Table 1 (continued)

\begin{tabular}{|c|c|c|c|}
\hline PDB code & Family & Source & Enzyme/protein \\
\hline 3LM1 & Moraceae & Maclura pomifera & Agglutinin \\
\hline $3 \mathrm{~S} 9 \mathrm{~V}$ & Pinaceae & Abies & Abietadiene synthase \\
\hline 3SAE & Pinaceae & Abies & Sesquiterpene synthase \\
\hline 3SDQ & Pinaceae & Abies & Sesquiterpene synthase \\
\hline 3SDR & Pinaceae & Abies & Sesquiterpene synthase \\
\hline 3SDT & Pinaceae & Abies & Sesquiterpene synthase \\
\hline $3 \mathrm{SDU}$ & Pinaceae & Abies & Sesquiterpene synthase \\
\hline 3SDV & Pinaceae & Abies & Sesquiterpene synthase \\
\hline $3 \mathrm{HBD}$ & Pinaceae & Picea & Chitinase \\
\hline $3 \mathrm{HBE}$ & Pinaceae & Picea & Chitinase \\
\hline $3 \mathrm{HBH}$ & Pinaceae & Picea & Chitinase \\
\hline 1QYC & Pinaceae & Pinus & $\begin{array}{l}\text { Phenylcoumaran benzylic } \\
\text { ether reductase }\end{array}$ \\
\hline $1 \mathrm{UOU}$ & Pinaceae & Pinus & Stilbene synthase \\
\hline 1XES & Pinaceae & Pinus & Stilbene synthase \\
\hline $1 \mathrm{XET}$ & Pinaceae & Pinus & Stilbene synthase \\
\hline 4LEJ & Pinaceae & Pinus & Vicilin \\
\hline $4 \mathrm{~N} 6 \mathrm{~T}$ & Salicaceae & Populus (poplar) & Adhiron (de novo prot) \\
\hline $4 \mathrm{~N} 6 \mathrm{U}$ & Salicaceae & Populus (poplar) & Adhiron (de novo prot) \\
\hline 3A9U & Salicaceae & Populus (poplar) & Coumarate CoA ligase \\
\hline $3 \mathrm{~A} 9 \mathrm{~V}$ & Salicaceae & Populus (poplar) & Coumarate CoA ligase \\
\hline $3 \mathrm{NI} 2$ & Salicaceae & Populus (poplar) & Coumarate CoA ligase \\
\hline 1Z7P & Salicaceae & Populus (poplar) & Glutaredoxin $\mathrm{C}^{\mathrm{a}}$ \\
\hline $1 \mathrm{Z7R}$ & Salicaceae & Populus (poplar) & Glutaredoxin $\mathrm{C}^{\mathrm{a}}$ \\
\hline 2E7P & Salicaceae & Populus (poplar) & Glutaredoxin $\mathrm{C}^{\mathrm{a}}$ \\
\hline No deposit & Salicaceae & Populus (poplar) & $\begin{array}{l}\text { Glutaredoxin C4 NMR } \\
\text { crystallography }^{\mathrm{a}}\end{array}$ \\
\hline $3 \mathrm{FZ9}$ & Salicaceae & Populus (poplar) & Glutaredoxin $\mathrm{S} 12^{\mathrm{a}}$ \\
\hline 3FZA & Salicaceae & Populus (poplar) & Glutaredoxin $\mathrm{S} 12^{\mathrm{a}}$ \\
\hline 2LKU & Salicaceae & Populus (poplar) & Glutaredoxin S14 apo NMR ${ }^{\mathrm{a}}$ \\
\hline 2LKU & Salicaceae & Populus (poplar) & Glutaredoxin S14 NMR ${ }^{\mathrm{a}}$ \\
\hline 2P5Q & Salicaceae & Populus (poplar) & Glutathione peroxidase $\mathrm{Gpx} 5^{\mathrm{a}}$ \\
\hline 2P5R & Salicaceae & Populus (poplar) & Glutathione peroxidase $\mathrm{Gpx} 5^{\mathrm{a}}$ \\
\hline $4 \mathrm{PQH}$ & Salicaceae & Populus (poplar) & Glutathione $\mathrm{S}$ transferase $\mathrm{L}^{\mathrm{a}}$ \\
\hline 4PQI & Salicaceae & Populus (poplar) & Glutathione $\mathrm{S}$ transferase $\mathrm{L}^{\mathrm{a}}$ \\
\hline $3 \mathrm{~N} 0 \mathrm{~F}$ & Salicaceae & Populus (poplar) & Isoprene synthase \\
\hline $3 \mathrm{~N} 0 \mathrm{G}$ & Salicaceae & Populus (poplar) & Isoprene synthase \\
\hline $2 \mathrm{~J} 89$ & Salicaceae & Populus (poplar) & $\begin{array}{l}\text { Methionine sulfoxide } \\
\text { reductase } \mathrm{A}^{\mathrm{a}}\end{array}$ \\
\hline $1 \mathrm{JXG}$ & Salicaceae & Populus (poplar) & Plastocyanin \\
\hline 1PLC & Salicaceae & Populus (poplar) & Plastocyanin \\
\hline 1PNC & Salicaceae & Populus (poplar) & Plastocyanin \\
\hline 1PND & Salicaceae & Populus (poplar) & Plastocyanin \\
\hline $2 \mathrm{PCY}$ & Salicaceae & Populus (poplar) & Plastocyanin \\
\hline $3 \mathrm{PCY}$ & Salicaceae & Populus (poplar) & Plastocyanin \\
\hline 4DP0 & Salicaceae & Populus (poplar) & Plastocyanin \\
\hline 4DP1 & Salicaceae & Populus (poplar) & Plastocyanin \\
\hline 4DP2 & Salicaceae & Populus (poplar) & Plastocyanin \\
\hline 4DP4 & Salicaceae & Populus (poplar) & Plastocyanin \\
\hline 4DP5 & Salicaceae & Populus (poplar) & Plastocyanin \\
\hline
\end{tabular}


Table 1 (continued)

\begin{tabular}{|c|c|c|c|}
\hline PDB code & Family & Source & Enzyme/protein \\
\hline 4DP6 & Salicaceae & Populus (poplar) & Plastocyanin \\
\hline 4DP7 & Salicaceae & Populus (poplar) & Plastocyanin \\
\hline 4DP8 & Salicaceae & Populus (poplar) & Plastocyanin \\
\hline 4DP9 & Salicaceae & Populus (poplar) & Plastocyanin \\
\hline 4DPA & Salicaceae & Populus (poplar) & Plastocyanin \\
\hline 4DPB & Salicaceae & Populus (poplar) & Plastocyanin \\
\hline 4DPC & Salicaceae & Populus (poplar) & Plastocyanin \\
\hline $4 \mathrm{PCY}$ & Salicaceae & Populus (poplar) & Plastocyanin \\
\hline $5 \mathrm{PCY}$ & Salicaceae & Populus (poplar) & Plastocyanin \\
\hline $6 \mathrm{PCY}$ & Salicaceae & Populus (poplar) & Plastocyanin \\
\hline $1 \mathrm{TKW}$ & Salicaceae & Populus (poplar) & Plastocyanin cyt $\mathrm{f}$ complex \\
\hline $1 \mathrm{SI} 9$ & Salicaceae & Populus (poplar) & Protein SP1 heat stable \\
\hline $1 \mathrm{TRO}$ & Salicaceae & Populus (poplar) & Protein SP1 heat stable \\
\hline 1YQD & Salicaceae & Populus (poplar) & Sinapyl alcohol dehydrogenase \\
\hline 1YQX & Salicaceae & Populus (poplar) & Sinapyl alcohol dehydrogenase \\
\hline $1 \mathrm{TI} 3$ & Salicaceae & Populus (poplar) & Thioredoxin $\mathrm{h} 1^{\mathrm{a}}$ \\
\hline 3D21 & Salicaceae & Populus (poplar) & Thioredoxin $\mathrm{h} 4^{\mathrm{a}}$ \\
\hline $3 \mathrm{D} 22$ & Salicaceae & Populus (poplar) & Thioredoxin $\mathrm{h} 4^{\mathrm{a}}$ \\
\hline $1 \mathrm{TP} 9$ & Salicaceae & Populus (poplar) & Type II peroxiredoxin ${ }^{\mathrm{a}}$ \\
\hline 1UMZ & Salicaceae & Populus (poplar) & Xyloglucan endotransglycolase \\
\hline 1UN1 & Salicaceae & Populus (poplar) & Xyloglucan endotransglycolase \\
\hline $2 \mathrm{YII}$ & Taxaceae & Taxus & Phenylalanine amino mutase \\
\hline $4 \mathrm{BAA}$ & Taxaceae & Taxus & Phenylalanine amino mutase \\
\hline $4 \mathrm{BAB}$ & Taxaceae & Taxus & Phenylalanine amino mutase \\
\hline $4 \mathrm{C} 5 \mathrm{R}$ & Taxaceae & Taxus & Phenylalanine amino mutase \\
\hline $4 \mathrm{C} 5 \mathrm{~S}$ & Taxaceae & Taxus & Phenylalanine amino mutase \\
\hline $4 \mathrm{C} 5 \mathrm{U}$ & Taxaceae & Taxus & Phenylalanine amino mutase \\
\hline $4 \mathrm{C} 6 \mathrm{G}$ & Taxaceae & Taxus & Phenylalanine amino mutase \\
\hline 4CQ5 & Taxaceae & Taxus & Phenylalanine amino mutase \\
\hline $3 \mathrm{NZ4}$ & Taxaceae & Taxus & Taxadiene synthase \\
\hline 3P5P & Taxaceae & Taxus & Taxadiene synthase \\
\hline 3P5R & Taxaceae & Taxus & Taxadiene synthase \\
\hline
\end{tabular}

model species for trees but it is of course not the only one for plants in general and remarkable advances have been done in the past with spinach or pea high molecular weight enzymes as RubisCO and LHC (Knight et al. 1990; Standfuss et al. 2005; Barros et al. 2009).

\section{Tree system biology: what could be contribution of structural proteomics?}

Massive information from genome sequencing needs now to be organized into a systems biology database in order to understand the structure-function relationships of individual proteins (Dietz et al. 2010). Besides, the characterization of protein-protein interactions obviously requires working at the protein level. Still, even the genome organization helps in this respect. We have given above a couple examples explaining how the genes coding for separate proteins working together in poplar can be found linked together in bacteria, leading to the production of hybrid enzymes. A take home message is that one should systematically look for such possible associations in prokaryotic genomes. The results of this systematic genomic data-mining can be sometimes extremely informative. Alternatively, genetic engineering allows the production of recombinant enzymes that can be used 
Table 2 Known non-forest tree protein structures

\begin{tabular}{|c|c|c|c|}
\hline pdf \# & Family & Source & Enzyme/protein \\
\hline $3 \mathrm{G} 4 \mathrm{~F}$ & Malvaceae & Cotton, Gossypium arboreum & Cadinene synthase \\
\hline $3 G 4 D$ & Malvaceae & Cotton, Gossypium arboreum & Cadinene synthase \\
\hline 3BRX & Malvaceae & Cotton, Gossypium hirsutum & Annexin \\
\hline $1 \mathrm{~N} 00$ & Malvaceae & Cotton, Gossypium hirsutum & Annexin \\
\hline $2 \mathrm{JON}$ & Oleaceae & Olive & Allergen \\
\hline $1 \mathrm{SS} 3$ & Oleaceae & Olive & Allergen \\
\hline $1 \mathrm{~B} 8 \mathrm{G}$ & Rosaceae & Apple & ACC synthase \\
\hline $1 \mathrm{M} 4 \mathrm{~N}$ & Rosaceae & Apple & ACC synthase \\
\hline $1 \mathrm{M} 7 \mathrm{Y}$ & Rosaceae & Apple & ACC synthase \\
\hline $1 \mathrm{YNU}$ & Rosaceae & Apple & ACC synthase \\
\hline 3PIU & Rosaceae & Apple & ACC synthase \\
\hline $3 Z \mathrm{ZS} 3$ & Rosaceae & Apple & Thaumatin like \\
\hline 1IQQ & Rosaceae & Pyrus, pear & Pistil ribonuclease \\
\hline 1E09 & Rosaceae & Prunus & Pru Av1 cherry allergen \\
\hline $1 \mathrm{H} 2 \mathrm{O}$ & Rosaceae & Prunus & Pru Av1 cherry allergen \\
\hline 1JU2 & Rosaceae & Prunus & Hydroxy nitryle lyase \\
\hline $2 \mathrm{AHN}$ & Rosaceae & Prunus & Pru Av2 allergen \\
\hline $2 \mathrm{ALG}$ & Rosaceae & Prunus & Pru P (LTP) \\
\hline 2B5S & Rosaceae & Prunus & Pru P (LTP) \\
\hline $3 \mathrm{EHK}$ & Rosaceae & Prunus & Allergenic protein \\
\hline $3 \mathrm{FZ3}$ & Rosaceae & Prunus & Almond Pru I allergenic \\
\hline $3 \mathrm{GDN}$ & Rosaceae & Prunus & Hydroxy nitryle lyase \\
\hline 3GDP & Rosaceae & Prunus & Hydroxy nitryle lyase \\
\hline 3RED & Rosaceae & Prunus & Hydroxy nitryle lyase \\
\hline 2EFJ & Rubiaceae & Coffee & 3,7-Dimethylxanthine methyltransferase \\
\hline 2EG5 & Rubiaceae & Coffee & Xanthosine methyl transferase \\
\hline $4 \mathrm{G} 22$ & Rubiaceae & Coffee & Lys HCT \\
\hline 4G0B & Rubiaceae & Coffee & Lys HCT \\
\hline $4 \mathrm{G} 2 \mathrm{M}$ & Rubiaceae & Coffee & Lys HCT \\
\hline $2 \mathrm{M} 70$ & Rutaceae & Citrus & Poly(A)-binding protein 1 \\
\hline $3 \mathrm{WD} 7$ & Rutaceae & Citrus & Polyketide synthase \\
\hline $3 \mathrm{WD} 8$ & Rutaceae & Citrus & Polyketide synthase \\
\hline 4JJM & Rutaceae & Citrus & Cyclophilin \\
\hline
\end{tabular}

for biochemical determination and also for protein structural work. Very elegant fishing techniques such as the yeast two-hybrid system or bimolecular fluorescence complementation experiments can be used to fish or validate potential protein ligands for a given protein. Still another avenue for research is the structural determination of tree proteins, though it requires first access to the genes of a given organism. Given the present high-throughput of tree genome sequencing, we postulate that tree protein structural genomics should soon take off. As we have detailed in this paper, the field is still very much in infancy with the structures of only $c a 70$ individual tree proteins that have been solved up to now. We believe that the future of tree protein structure determination is very bright indeed, given its interesting potential for systems biology improvement.

Acknowledgments This work was supported by a grant overseen by the French National Research Agency (ANR) as part of the "Investissements d'Avenir" program (ANR-11-LABX-0002-01, Lab of Excellence ARBRE). The visit of Desirée Gütle is supported by a grant overseen by the French National Research Agency (ANR) as part of the "Investissements d'Avenir" program (ANR-11-LABX-0002-01, Lab of Excellence ARBRE). Her PhD grant is from the French MENRT 


\section{References}

Azri W, Brunel N, Franchel J, Ben Rejeb I, Jacquot JP, Julien JL, Herbette S, Roeckel-Drevet P (2013) Putative role of thioredoxin h in response to gravitropic stimulation of poplar stems. J Plant Physiol 170:707-711

Balmer Y, Vensel WH, Tanaka CK, Hurkman WJ, Gelhaye E, Rouhier N, Jacquot JP, Manieri W, Schürmann P, Droux M, Buchanan BB (2004) Thioredoxin links redox to the regulation of fundamental processes of plant mitochondria. Proc Natl Acad Sci U S A 101: 2642-2647

Bandyopadhyay S, Gama F, Molina-Navarro MM, Gualberto JM, Claxton R, Naik SG, Huynh BH, Herrero E, Jacquot JP, Johnson MK, Rouhier N (2008) Chloroplast monothiol glutaredoxins act as scaffold proteins for the assembly and delivery of [2Fe-2S] clusters. EMBO J 27:1122-1133

Barros T, Royant A, Standfuss J, Dreuw A, Kühlbrandt W (2009) Crystal structure of plant light-harvesting complex shows the active, energytransmitting state. EMBO J 28:298-306

Birol I, Raymond A, Jackman SD, Pleasance S, Coope R, Taylor GA, Saint Yuen MM, Keeling CI, Brand D, Vandervalk BP, Kirk H, Pandoh P, Moore RA, Zhao YJ, Mungall AJ, Jaquish B, Yanchuk A, Ritland C, Boyle B, Bousquet J, Ritland K, MacKay J, Bohlmann J, Jones SJM (2013) Assembling the $20 \mathrm{~Gb}$ white spruce (Picea glauca) genome from whole genome shotgun sequencing data. Bioinformatics 29:1492-1497

Bréheĺin C, Mouaheb N, Verdoucq L, Lancelin JM, Meyer Y (2000) Characterization of determinants for the specificity of Arabidopsis thioredoxins $\mathrm{h}$ in yeast complementation. J Biol Chem 275: 31641-31647

Bunik V, Raddatz G, Lemaire S, Meyer Y, Jacquot JP, Bisswanger H (1999) Interaction of thioredoxins with target proteins: role of particular structural elements and electrostatic properties of thioredoxins in their interplay with 2-oxoaciddehydrogenase complexes. Protein Sci 8:65-74

Chiadmi M, Navaza A, Miginiac-Maslow M, Jacquot JP, Cherfils J (1999) Redox signaling in the chloroplast: structure of the oxidized pea fructose-1,6-bisphosphatase. EMBO J 18:6809-6815

Chibani K, Wingsle G, Jacquot JP, Gelhaye E, Rouhier N (2009) Comparative study of the thioredoxin family in photosynthetic organisms with emphasis on Populus trichocarpa. Mol Plant 2: 308-322

Chibani K, Tarrago L, Schürmann P, Jacquot JP, Rouhier N (2011) Biochemical properties of poplar thioredoxin z. FEBS Lett 585: 1077-1081

Chibani K, Tarrago L, Gualberto JM, Wingsle G, Rey P, Jacquot JP, Rouhier N (2012) Atypical thioredoxins in poplar: the glutathionedependent thioredoxin-like 2.1 supports the activity of target enzymes possessing a single redox active cysteine. Plant Physiol 159: 592-605

Coudevylle N, Thureau A, Hemmerlin C, Gelhaye E, Jacquot JP, Cung MT (2004) Letter to the Editor: ${ }^{1} \mathrm{H},{ }^{13} \mathrm{C}$ and ${ }^{15} \mathrm{~N}$ resonance assignment of the reduced form of thioredoxin $\mathrm{h} 1$ of poplar, a CPPC active site variant. J Biomol NMR 30:229-230

Coudevylle N, Thureau A, Hemmerlin C, Gelhaye E, Jacquot JP, Cung MT (2005) Solution structure of a natural CPPC active site variant, thioredoxin h1 from poplar. Biochemistry 44:2001-2008

Couturier J, Jacquot JP, Rouhier N (2009a) Evolution and diversity of glutaredoxins in photosynthetic organisms. Cell Mol Life Sci 66: 2539-2545

Couturier J, Koh CS, Zaffagnini M, Winger AM, Gualberto JM, Corbier C, Decottignies P, Jacquot JP, Lemaire SD, Didierjean C, Rouhier N (2009b) Structure-function relationship of the chloroplastic glutaredoxin S12 with an atypical WCSYS active site. J Biol Chem 284:9299-9310
Couturier J, Didierjean C, Jacquot JP, Rouhier N (2010) Engineered mutated glutaredoxins mimicking peculiar plant class III glutaredoxins bind iron sulphur centers and possess reductase activity. Biochem Biophys Res Commun 403:435-441

Couturier J, Ströher E, Albetel AN, Roret T, Muthuramalingam M, Tarrago L, Seidel T, Tsan P, Jacquot JP, Johnson MK, Dietz KJ, Didierjean C, Rouhier N (2011) Arabidopsis chloroplastic glutaredoxin $\mathrm{C} 5$ to explore molecular determinants for iron sulfur cluster binding into glutaredoxins. J Biol Chem 286:27515-27527

Couturier J, Vignols F, Jacquot JP, Rouhier N (2012) Glutathione- and glutaredoxin-dependent reduction of methionine sulfoxide reductase A. FEBS Lett 586:3894-3899

Couturier J, Jacquot JP, Rouhier N (2013a) Toward a refined classification of class I dithiol glutaredoxins from poplar: biochemical basis for the definition of two subclasses. Front Plant Sci 4:518

Couturier J, Prosper P, Winger AM, Hecker A, Hirasawa M, Knaff DB, Gans P, Jacquot JP, Navaza A, Haouz A, Rouhier N (2013b) In the absence of thioredoxin what are the reductants for peroxiredoxin in Thermotoga maritima? Antioxid Redox Signal 18:1613-1622

Couturier J, Wu HC, Dhalleine T, Pégeot H, Sudre D, Gualberto JM, Jacquot JP, Gaymard F, Vignols F, Rouhier N (2014) Monothiol glutaredoxin-BolA interactions: redox control of Arabidopsis thaliana BolA2 ans SufE1. Mol Plant 7:187-205

d'Ambrosio K, Kauffmann B, Rouhier N, Benedetti E, Jacquot JP, Aubry A, Corbier C (2003) Crystallization and preliminary X ray data of poplar glutaredoxin. Acta Crystallogr Ser D 59:1043-1045

Dietz KJ, Jacquot JP, Harris G (2010) Hubs and bottlenecks in plant molecular signaling networks. New Phytol 188:919-938

Echalier A, Trivelli X, Corbier C, Rouhier N, Walker O, Tsan P, Jacquot JP, Aubry A, Krimm I, Lancelin JM (2005) X ray and NMR studies of a homodimeric D (type II) peroxiredoxin reduced by both glutaredoxin and thioredoxin: Prx-Prx interfaces in the Prx family. Biochemistry 44:1755-1767

Feldmann KA, Goff SA (2013) The first plant genome sequenceArabidopsis thaliana. Adv Bot Res 69:92-112

Feng Y, Rouhier N, Jacquot JP, Xia B $(2005){ }^{1} \mathrm{H},{ }^{15} \mathrm{~N}$, and ${ }^{13} \mathrm{C}$ resonance assignments of reduced glutaredoxin $\mathrm{C} 1$ from Populus tremula $\mathrm{x}$ tremuloides. J Biomol NMR 31:263-264

Feng Y, Shong N, Rouhier N, Hase T, Kusunoki M, Jacquot JP, Jin C, Xia B (2006) Structural insight into poplar glutaredoxin C1 with a bridging iron sulfur center near the active site. Biochemistry 45 : 7998-8008

Gama F, Keech O, Eymery F, Finkemeier I, Gelhaye E, Gardestrom P, Dietz K-J, Rey P, Jacquot J-P, Rouhier N (2007) The mitochondrial type II peroxiredoxin from poplar. Physiol Plant 129:196-206

Gama F, Bréhélin C, Gelhaye E, Meyer Y, Jacquot JP, Rey P, Rouhier N (2008) Functional analysis and expression characteristics of chloroplastic peroxiredoxin IIE. Physiol Plant 133:599-610

Gelhaye E, Rouhier N, Vlamis-Gardikas A, Girardet JM, Sautière PE, Sayzet M, Jacquot JP (2003a) Identification and characterization of a third thioredoxin $\mathrm{h}$ in poplar. Plant Physiol Biochem 41:629-635

Gelhaye E, Rouhier N, Jacquot JP (2003b) Evidence for a subgroup of thioredoxin $\mathrm{h}$ that requires GSH/Grx for its reduction. FEBS Lett 555:443-448

Gelhaye E, Rouhier N, Gerard J, Jolivet Y, Gualberto J, Navrot N, Ohlsson PI, Wingsle G, Hirasawa M, Knaff DB, Wang H, Dizengremel P, Meyer Y, Jacquot JP (2004) A specific form of thioredoxin $\mathrm{h}$ occurs in plant mitochondria and regulates the alternative oxidase. Proc Natl Acad Sci U S A 101:14545-14550

Gelhaye E, Rouhier N, Navrot N, Jacquot JP (2005) The plant thioredoxin system. Cell Mol Life Sci 62:24-35

Guo WJ, Li P, Ling J, Ye SP (2007) Significant comparative characteristics between orphan and nonorphan genes in the rice (Oryza sativa L.) genome. Comp Funct Genomics. Article ID 21676, 7 pages

Guss JM, Freeman HC (1983) Structure of oxidized poplar plastocyanin at 1.6 A resolution. J Mol Biol 169:521-563 
Jacquot JP, Lopez-Jaramillo J, Chueca A, Cherfils J, Lemaire S, Chedozeau B, Miginiac-Maslow M, Decottignies P, Wolosiuk R, Lopez-Gorge J (1995) High level expression of recombinant pea fructose-1,6-bisphosphatase and mutagenesis of its regulatory site. Eur J Biochem 229:675-681

Jacquot JP, Eklund H, Rouhier N, Schürmann P (2009) Structural en evolutionary aspects of thioredoxin reductases in photosynthetic organisms. Trends Plant Sci 14:336-343

Kim SJ, Woo JR, Hwang YS, Jeong DG, Shin DH, Kim K, Ryu SE (2003) The tetrameric structure of Haemophilus influenzae hybrid Prx5 reveals interactions between electron donor and acceptor proteins. J Biol Chem 278:10790-10798

Knight S, Andersson I, Brändén CI (1990) Crystallographic analysis of ribulose 1,5-bisphosphate carboxylase from spinach at 2.4 A resolution. Subunit interactions and active site. J Mol Biol 215:113-160

Koh CS, Didierjean C, Navrot N, Panjikar S, Mulliert G, Jacquot JP, Rouhier N, Aubry A, Shawakataly O, Corbier C (2007) Crystal structures of poplar thioredoxin peroxidase which exhibits the structure of glutathione peroxidases: insights into redox driven conformational changes. J Mol Biol 370:512-529

Koh CS, Navrot N, Didierjean C, Rouhier N, Hirasawa M, Knaff DB, Wingsle G, Samian R, Jacquot JP, Corbier C, Gelhaye E (2008) An atypical catalytic mechanism involving three cysteines of thioredoxin. J Biol Chem 283:23062-23072

Lallement PA, Brouwer B, Keech O, Hecker A, Rouhier N (2014a) The still mysterious roles of cysteine-containing glutathione transferases in plants. Front Pharmacol. doi:10.3389/fphar.2014.00192

Lallement PA, Meux E, Gualberto JM, Prosper P, Didierjean C, Saul F, Haouz A, Rouhier N, Hecker A (2014b) Structural and enzymatic insights into Lambda glutathione transferases from Populus trichocarpa, monomeric enzymes constituting an early divergent class specific to terrestrial plants. Biochem J 462:39-52

Lan T, Yang ZL, Yang X, Liu YJ, Wang XR, Zeng QY (2009) Extensive functional diversification of the Populus glutathione- $S$-transferase supergene family. Plant Cell 21:3749-3766

Li S, Lauri A, Ziemann M, Busch A, Bhave M, Zachgo S (2009) Nuclear activity of Roxy, a glutaredoxin interacting with TGA transcription factors is required for petal development in Arabidopsis thaliana. Plant Cell 21:429-441

Menchise V, Corbier C, Didierjean C, Saviano M, Benedetti E, Jacquot JP, Aubry A (2001) Crystal structure of the wild type and D30A mutant of Chlamydomonas reinhardtii and implications for the catalytic mechanism. Biochem J 359:65-75

Michael TP, Jackson S (2013) The first 50 plant genomes. Plant Genome 6:1-7

Myburg AA, Grattapaglia D, Tuskan GA, Hellsten U, Hayes RD, Grimwood J, Jenkins J, Lindquist E, Tice H, Bauer D, Goodstein DM, Dubchak I, Poliakov A, Mizrachi E, Kullan AR, Hussey SG, Pinard D, van der Merwe K, Singh P, van Jaarsveld I, Silva-Junior OB, Togawa RC, Pappas MR, Faria DA, Sansaloni CP, Petroli CD, Yang X, Ranjan P, Tschaplinski TJ, Ye CY, Li T, Sterck L, Vanneste K, Murat F, Soler M, Clemente HS, Saidi N, Cassan-Wang H, Dunand C, Hefer CA, Bornberg-Bauer E, Kersting AR, Vining K, Amarasinghe V, Ranik M, Naithani S, Elser J, Boyd AE, Liston A, Spatafora JW, Dharmwardhana P, Raja R, Sullivan C, Romanel E, Alves-Ferreira M, Külheim C, Foley W, Carocha V, Paiva J, Kudrna D, Brommonschenkel SH, Pasquali G, Byrne M, Rigault P, Tibbits J, Spokevicius A, Jones RC, Steane DA, Vaillancourt RE, Potts BM, Joubert F, Barry K, Pappas GJ, Strauss SH, Jaiswal P, GrimaPettenati J, Salse J, Van de Peer Y, Rokhsar DS, Schmutz J (2014) The genome of Eucalyptus grandis. Nature 510:356-362

Navrot N, Collin V, Gualberto J, Gelhaye E, Hirasawa M, Rey P, Knaff DB, Issakidis E, Jacquot JP, Rouhier N (2006) Plant glutathione peroxidases are functional peroxiredoxins distributed in several subcellular compartments and regulated during biotic and abiotic stresses. Plant Physiol 142:1364-1379
Neale DB, Wegrzyn JL, Stevens KA, Zimin AV, Puiu D, Crepeau MW et al (2014) Decoding the massive genome of loblolly pine using haploid DNA and novel assembly strategies. Genome Biol 15:R59

Noguera V, Walker O, Rouhier N, Jacquot JP, Krimm I, Lancelin JM (2005) NMR reveals a novel glutaredoxin-glutaredoxin interaction interface. J Mol Biol 353:629-641

Noguera-Mazon V, Lemoine J, Walker O, Rouhier N, Salvador A, Jacquot JP, Lancelin JM, Krimm I (2006) Glutathionylation induces the dissociation of 1-Cys D-peroxiredoxin non-covalent homodimer. J Biol Chem 281:31736-31742

Nystedt B, Street NR, Wetterbom A, Zuccolo A, Lin YC, Scofield DG, Vezzi F, Delhomme N, Giacomello S, Alexeyenko A, Vicedomini R, Sahlin K, Sherwood E, Elfstrand M, Gramzow L, Holmberg K, Hallman J, Keech O, Klasson L, Koriabine M, Kucukoglu M, Kaller M, Luthman J, Lysholm F, Niittyla T, Olson A, Rilakovic N, Ritland C, Rossello JA, Sena J et al (2013) The Norway spruce genome sequence and conifer genome evolution. Nature 497:579-584

Perez-Jimenez R, Li J, Kosuri P, Sanchez-Romero I, Wiita AP, Rodriguez-Larrea D, Chueca A, Holmgren A, Miranda-Vizuete A, Becker K, Cho SH, Beckwith J, Gelhaye E, Jacquot JP, Gaucher EA, Sanchez-Ruiz JM, Berne BJ, Fernandez JM (2009) Diversity of chemical mechanisms in thioredoxin catalysis revealed by singlemolecule force spectroscopy. Nat Struct Mol Biol 16:890-896

Rahman AY, Usharraj AO, Misra BB, Thottathil GP, Jayasekaran K, Feng Y, Hou S, Ong SY, Ng FL, Lee LS, Tan HS, Sakaff MK, Teh BS, Khoo BF, Badai SS, Aziz NA, Yuryev A, Knudsen B, Dionne-Laporte A, Mchunu NP, Yu Q, Langston BJ, Freitas TA, Young AG, Chen R, Wang L, Najimudin N, Saito JA, Alam M (2013) Draft genome sequence of the rubber tree Hevea brasiliensis. BMC Genomics 14:75

Rodríguez-Manzaneque MT, Tamarit J, Bellí G, Ros J, Herrero E (2002) Grx 5 is a mitochondrial glutaredoxin required for the activity of iron sulfur enzymes. Mol Biol Cell 13:1109-1121

Roret T, Tsan P, Couturier J, Zhang B, Johnson MK, Rouhier N, Didierjean C (2014) Structural and spectroscopic insights into BolA-glutaredoxin complexes. J Biol Chem. doi:10.1074/jbc. M114.572701

Rouhier N, Jacquot JP (2003) Molecular and catalytic properties of a peroxiredoxin-glutaredoxin hybrid from Neisseria meningitidis. FEBS Lett 554:149-153

Rouhier N, Jacquot JP (2005) The plant multigenic family of thioredoxin peroxidases. Free Radic Biol Med 38:1413-1421

Rouhier N, Gelhaye E, Sautiere PE, Brun A, Laurent P, Tagu D, Gerard J, de Fay E, Meyer Y, Jacquot JP (2001) Isolation and characterization of a new peroxiredoxin from poplar sieve tubes that uses either glutaredoxin or thioredoxin as a proton donor. Plant Physiol 127: 1299-1309

Rouhier N, Gelhaye E, Jacquot JP (2002a) Glutaredoxin dependent peroxiredoxin from poplar: protein-protein interaction and catalytic mechanism. J Biol Chem 277:13609-13614

Rouhier N, Gelhaye E, Sautière PE, Jacquot JP (2002b) Enhancement of poplar glutaredoxin expression by optimization of the cDNA sequence. Protein Expr Purif 24:234-241

Rouhier N, Vlamis-Gardikas A, Lillig CH, Berndt C, Schwenn JD, Holmgren A, Jacquot JP (2003) Characterization of the redox properties of poplar glutaredoxin. Antioxid Redox Signal 5:15-22

Rouhier N, Gelhaye E, Jacquot JP (2004a) Plant glutaredoxins: still mysterious reducing systems. Cell Mol Life Sci 61:1266-1277

Rouhier N, Gelhaye E, Gualberto J, Jordy MN, de Fay E, Hirasawa M, Duplessis S, Lemaire S, Frey P, Martin F, Manieri W, Knaff DB, Jacquot JP (2004b) Poplar peroxiredoxin Q: a thioredoxin-linked chloroplast antioxidant functional in pathogen defense. Plant Physiol 134:1027-1038

Rouhier N, Villarejo A, Srivastava M, Gelhaye E, Keech O, Droux M, Finkemeier I, Samuelsson G, Dietz KJ, Jacquot JP, Wingsle G (2005) Identification of plant glutaredoxin targets. Antioxid Red Signal 7:919-929 
Rouhier N, Couturier J, Jacquot JP (2006a) Genome wide analysis of plant glutaredoxin systems. J Exp Bot 57:1685-1696

Rouhier N, Gama F, Wingsle G, Gelhaye E, Gans P, Jacquot JP (2006b) Engineering functional artificial hybrid proteins between poplar peroxiredoxin II and glutaredoxin or thioredoxin. Biochem Biophys Res Commun 341:1300-1308

Rouhier N, Kauffmann B, Tete-Favier F, Paladino P, Gans P, Branlant G, Jacquot JP, Boschi-Muller S (2007a) Functional and structural aspects of poplar cytosolic and plastidial type A methionine sulfoxide reductases. J Biol Chem 282:3367-3378

Rouhier N, Unno H, Bandyopadhay S, Masip L, Kim SK, Hirasawa M, Gualberto J, Lattard V, Kusunoki M, Knaff DB, Georgiou G, Hase T, Johnson MK, Jacquot JP (2007b) Functional, structural and spectroscopic characterization of a glutathione-ligated [2Fe-2S] cluster in poplar glutaredoxin C1. Proc Natl Acad Sci U S A 104:7379-7384

Rouhier N, Lemaire S, Jacquot JP (2008) The role of glutathione in photosynthetic organisms: emerging functions for glutaredoxins and glutathionylation. Annu Rev Plant Biol 59:143-166

Rouhier N, Couturier J, Johnson MK, Jacquot JP (2010) Glutaredoxins: role in iron komeostasis. Trends Biochem Sci 35:43-52

Schürmann P, Jacquot JP (2000) Plant thioredoxins systems revisited. Annu Rev Plant Physiol Plant Mol Biol 51:371-400

Selles B, Rouhier N, Chibani K, Gama F, Jacquot JP (2009) Glutaredoxin: the missing link between thiol-disulfide oxidoreductases and iron sulfur enzymes. Adv Bot Res 52:405-436

Selles B, Hugo M, Trujillo M, Srivastava V, Wingsle G, Jacquot JP, Radi R, Rouhier N (2012) Hydroxyperoxide and peroxinitrite reductase activity of poplar thioredoxin-dependent glutathione peroxidase 5: kinetics, catalytic mechanism and oxidative inactivation. Biochem $\mathrm{J}$ 442:369-480

Standfuss J, Terwisscha van Scheltinga AC, Lamborghini M, Kühlbrandt W (2005) Mechanisms of photoprotection and nonphotochemical quenching in pea light-harvesting complex at $2.5 \AA$ resolution. EMBO J 24:919-928

Tarrago L, Laugier E, Zaffagnini M, Marchand C, Le Maréchal P, Rouhier N, Lemaire SD, Rey P (2009) Regeneration mechanisms of Arabidopsis thaliana methionine sulfoxide reductase B by glutaredoxins and thioredoxins. J Biol Chem 284:18963-18971

Tuskan GA, Difazio S, Jansson S, Bohlmann J, Grigoriev I, Hellsten U, Putnam N, Ralph S, Rombauts S, Salamov A, Schein J, Sterck L,
Aerts A, Bhalerao RR, Bhalerao RP, Blaudez D, Boerjan W, Brun A, Brunner A, Busov V, Campbell M, Carlson J, Chalot M, Chapman J, Chen GL, Cooper D, Coutinho PM, Couturier J, Covert S, Cronk Q, Cunningham R, Davis J, Degroeve S, Déjardin A, Depamphilis C, Detter J, Dirks B, Dubchak I, Duplessis S, Ehlting J, Ellis B, Gendler K, Goodstein D, Gribskov M, Grimwood J, Groover A, Gunter L, Hamberger B, Heinze B, Helariutta Y, Henrissat B, Holligan D, Holt $\mathrm{R}$, Huang $\mathrm{W}$, Islam-Faridi N, Jones S, Jones-Rhoades M, Jorgensen R, Joshi C, Kangasjärvi J, Karlsson J, Kelleher C, Kirkpatrick R, Kirst M, Kohler A, Kalluri U, Larimer F, Leebens-Mack J, Leplé JC, Locascio P, Lou Y, Lucas S, Martin F, Montanini B, Napoli C, Nelson DR, Nelson C, Nieminen K, Nilsson O, Pereda V, Peter G, Philippe R, Pilate G, Poliakov A, Razumovskaya J, Richardson P, Rinaldi C, Ritland K, Rouzé P, Ryaboy D, Schmutz J, Schrader J, Segerman B, Shin H, Siddiqui A, Sterky F, Terry A, Tsai CJ, Uberbacher E, Unneberg P, Vahala J, Wall K, Wessler S, Yang G, Yin T, Douglas C, Marra M, Sandberg G, Van de Peer Y, Rokhsar D (2006) The genome of black cottonwood, Populus trichocarpa. Science 313:1596-15604

Verdoucq L, Vignols F, Jacquot JP, Chartier Y, Meyer Y (1999) In vivo characterization of a thioredoxin $\mathrm{h}$ target protein defines a new peroxiredoxin family. J Biol Chem 274:19714-19722

Vieira Dos Santos C, Laugier E, Tarrago L, Massot V, Issakidis-Bourguet E, Rouhier N, Rey P (2007) Specifivity of thioredoxins and glutaredoxins as electron donors to two distinct classes of Arabidopsis plastidial methionine sulfoxide reductases B. FEBS Lett 581:4371-4376

Wang L, Ren X, Li Y, Rouhier N, Jacquot JP, Jin C, Xia B $(2011){ }^{1} \mathrm{H},{ }^{13} \mathrm{C}$, and ${ }^{15} \mathrm{~N}$ resonance assignments of reduced GrxS14 from Populus tremula $\times$ tremuloides. Biomol NMR Assign 5:121-124

Wang L, Ouyang B, Li Y, Feng Y, Jacquot JP, Rouhier N, Xia B (2012) Glutathione regulates the transfer of iron sulfur cluster from monothiol and dithiol glutaredoxins to apo ferredoxin. Protein Cell 3:714-721

Wang L, Li Y, Jacquot JP, Rouhier N, Xia B (2014) Characterization of poplar GrxS14 in different structural forms. Protein Cell 5: 329-333

Wissler L, Gadau J, Simola DF, Helmkampf M, Bornberg-Bauer E (2013) Mechanisms and dynamics of orphan gene emergence in insect genomes. Genome Biol Evol 5:439-455 